\title{
SIMULATED ACID AZO DYE WASTEWATER TREATMENT USING SUSPENDED GROWTH CONFIGURED SEQUENCING BATCH REACTOR (SBR) UNDER ANOXIC-AEROBIC-ANOXIC MICROENVIRONMENT
}

\author{
S. VENKATA MOHAN* - N. CHANDRASEKHARA RAO - P. N. SARMA \\ Bioengineering and Environmental Centre, Indian Institute of Chemical Technology, \\ Hyderabad 500 007, India (IICT communication number: 040801) \\ *Corresponding author \\ e-mail:vmohan_s@yahoo.com \\ (Received $29^{\text {th }}$ August 2005 ; accepted $6^{\text {th }}$ July 2009)
}

\begin{abstract}
Studies on the treatment of simulated acid metal complex azo dye (C.I.Acid black 210) wastewater was carried out in anoxic-aerobic-anoxic microenvironment using a periodically operated sequencing batch reactor (SBR) with suspended growth configuration at two organic loading rates $(0.56$ $\mathrm{Kg} \mathrm{COD/cum-day} \mathrm{and} 0.75 \mathrm{Kg} \mathrm{COD} / \mathrm{cum}$-day). The experimental data revealed the effective performance of the SBR system in the process of azo dye minerilazation, which may be attributed to the prevailing anoxic microenvironment present during the cycle operation. The reactor showed rapid startup (within 22 days) and stabilization (within 6 days after loading) compared to conventional continuously operated systems. Organic loading (shock loads) rates have shown relatively less effect on the performance.

Keywords: Simulated acid azo dye wastewater, Sequencing Batch Reactor (SBR), periodic discontinuous process, suspended growth configuration, oxygen consumption rate.
\end{abstract}

\section{Introduction}

Dyes are synthetic aromatic organic compounds, which are normally used for coloration of various substances. During textile processing, inefficiencies in dyeing result in large amounts of the dyestuff (varying from $2 \%$ loss when using basic dyes to a $50 \%$ loss when certain reactive dyes used) being directly lost to the wastewater, which ultimately finds its way into the environment [2-4]. Among all the chemical classes of dyes, azo dyes are considered to be recalcitrant, non-biodegradable and persistent [1]. Dye containing wastewater treatment is considered to be one of the challenging areas in the environmental fraternity. Eventhough physico-chemical methods are effective in dye removal, the overall cost, regeneration problem and associated problems of secondary sludge generation limits their application $[5,6]$. Dye containing wastewater is normally not amenable for conventional biological wastewater treatment due to the recalcitrant and inhibitory nature of the wastewater [7].

Biological treatment of dye containing wastewater is particularly challenging owing to the inhibition and/or toxicity of these compounds when they serve as microbial substrates. More recently researchers have been focusing their attention on the alternative approaches like periodic discontinuous process, which promotes the mineralization of toxic compounds. This is developed on the basic scientific assumption that periodic exposure of the microorganisms to defined process conditions is effectively achieved in a batch system and the exposure time, frequency of exposure and amplitude of the respective concentration can be set independent of any inflow condition [9]. In SBR mode operation the reactor volume varies with time, where as it 
remains constant in the traditional continuous flow system. From the process engineering point of view, the SBR system is distinguished by the enforcement of controlled short term unsteady state conditions leading in the long run to a stable steady state with respect to the composition and metabolic properties of the microbial population growing in the reactor by way of controlling the distribution and physiological state of the microorganisms [9]. Interest has been growing worldwide both in scientific research and in practical application of SBR technology. SBR has been successfully applied for the treatment of domestic wastewater, medium and lower strength landfill leachates, simulated dye wastewater's and contaminated soils [9-23]. This communication presents experimental data pertaining to the investigate carried out to treated simulated azo dye wastewater using suspended growth configured sequencing batch reactor (SBR).

\section{Materials and Methods}

\section{Simulated azo dye wastewater}

Acid Black EBR H/C (C.I Acid black 210), an acid dye belonging to azo (metal complex) chemical group was used in this study (gifted by M/s Atul Chemical Ltd, India). This dye was normally used for dyeing cotton and woolen fabric and has a solubility of $30 \mathrm{~g} / \mathrm{l}$ at $90^{\circ} \mathrm{C}$. The simulated dye wastewater was prepared prior to the experiments by dissolving the requisite amount of dye $(25 \mathrm{mg} / \mathrm{l}$ and $35 \mathrm{mg} / \mathrm{l})$ and glucose $(1 \mathrm{~g} / \mathrm{l})$ in tap water along with $10 \mathrm{ml}$ of nutrient solution (glucose- $1 \mathrm{~g}$; $\mathrm{MgSO}_{4} .7 \mathrm{H}_{2} \mathrm{O}-0.22 \mathrm{~g}, \mathrm{FeSO}_{4} .7 \mathrm{H}_{2} \mathrm{O}-0.5 \mathrm{~g}, \mathrm{NiSO}_{4} . \mathrm{H}_{2} \mathrm{O}-0.02 \mathrm{~g}, \mathrm{NaHCO}_{3}-5 \mathrm{~g}, \mathrm{NH}_{4} \mathrm{Cl}-1.3$ $\mathrm{g}, \mathrm{KH}_{2} \mathrm{PO}_{4}-0.05 \mathrm{~g}, \mathrm{CaCl}_{2}-0.058 \mathrm{~g}, \mathrm{FeCl}_{3} .6 \mathrm{H}_{2} \mathrm{O}-0.017 \mathrm{~g}, \mathrm{MnCl}_{2}-0.007 \mathrm{~g}, \mathrm{ZnCl}_{2}-0.004 \mathrm{~g}$, $\mathrm{CoCl}_{2} \cdot \mathrm{H}_{2} \mathrm{O}-0.004 \mathrm{~g}, \mathrm{NaBO}_{2} .10 \mathrm{H}_{2} \mathrm{O}-0.001 \mathrm{~g}$ dissolved in 11 distilled water [pH-7.0]).

\section{Reactor Operation}

SBR was fabricated in laboratory using perplex glass material with a designed volume (total) of 1.0 liters and working volume of 0.8 liters. The details of reactor configuration were presented elsewhere ${ }^{21}$. The outlet of the reactor used for wastewater withdrawal was provided at $0.025-\mathrm{m}$ length from the bottom of the reactor, which prevents biomass loss from the reactor after the settle phase is completed. The reactor was operated in suspended growth configuration in sequential batch mode at a constant room temperature $\left(26 \pm 2^{\circ} \mathrm{C}\right)$. SBR was operated with a total cycle period of 24 hours consisting of 30 minutes of fill phase, 23 hours of react (aerobic) phase with recycling, 15 minutes of settle phase and 15 minutes of decant phase.

Table 1. Details of sequence phase variation during cycle operation

\begin{tabular}{|l|l|l|l|l|}
\hline \multicolumn{1}{|c|}{ Phase } & \multicolumn{1}{|c|}{ Cycle period } & \multicolumn{1}{|c|}{ Air supply } & \multicolumn{1}{|c|}{ Recirculation } & \multicolumn{1}{c|}{$\begin{array}{c}\text { Convironment } \\
\text { Condion }\end{array}$} \\
\hline Fill & 30 minutes & Off & Off & Anoxic \\
React & 23 hours & On & On & Aerobic \\
Settle & 15 minutes & Off & Off & Anoxic \\
Decant & 15 minutes & Off & Of & Anoxic \\
\hline
\end{tabular}


Various sequence phases in the SBR operation was controlled by pre-programmed timers (ETTS, Germany). Feed, decant and recirculation operations were carried out using peristaltic pumps (Watson Marlow $101 \mathrm{U} / \mathrm{R}$ ). Recirculation at a rate of $1.6 \mathrm{l} / \mathrm{day}$ was maintained throughout the reactor operation to achieve a homogeneous distribution of substrate as well as uniform distribution of suspended biomass. During the reaction phase, aqueous phase dissolved oxygen (DO) was maintained in the range of 2.5 to 3.0 $\mathrm{mg} / \mathrm{l}$. The $\mathrm{pH}$ of the influent feed was adjusted to $7.1 \pm 0.1$ before feeding. The reactor was inoculated with aerobic biomass (VSS: $2.7 \mathrm{~g} / \mathrm{l}$ ) acquired from an operating laboratory scale SBR unit treating complex chemical wastewater. After inoculation, the reactor was operated with designed synthetic feed (organic loading rate (OLR) of $35 \mathrm{Kg}$ $\mathrm{COD} /$ cum-day) to build up the biomass. When the reactor approached VSS concentration of $2.5 \mathrm{~g} / \mathrm{l}$, simulated dye wastewater at an OLR of $0.35 \mathrm{Kg}$ COD/cum-day was loaded and subsequently after stable performance was achieved, the reactor was further operated at higher OLR $(0.75 \mathrm{Kg}$ COD/cum-day).

\section{Analytical Protocols}

Dye colour was estimated quantitatively by calorimetric procedure using the UV-VIS Spectrophotometer (Bechman, USA) at optimum wavelength $\left(\lambda_{\max }\right)$ of $617 \mathrm{~nm}$. Sample from the reactor was centrifuged $\left(3000 \mathrm{~g}, 28^{\circ} \mathrm{C}\right)$ and the supernatant was assayed for the residual dye colour concentration. The performance of the reactor was also assessed by monitoring COD, $\mathrm{pH}$, ORP, colour, SVI, VSS, SS, oxygen consumption rate (OCR) and dissolved oxygen (DO) throughout the reactor operation. The analytical procedures for estimating the above parameters were adopted from the procedures outlined in the standard methods [24].

\section{Results and Discussion}

After inoculation the reactor has taken 22 days (i.e. 22 cycles) for initial startup.

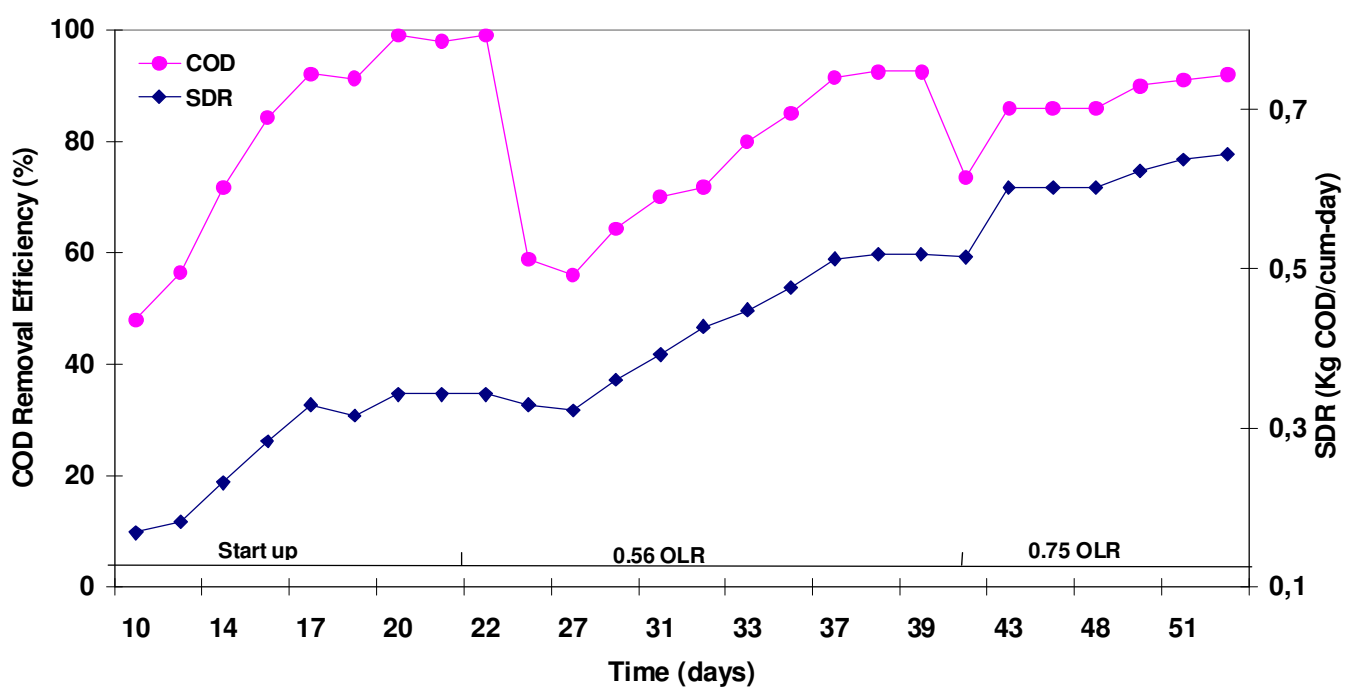

Figure 1. COD and SDR variation during reactor operation 
During startup phase reactor was operated with the designed synthetic feed (glucose as sole carbon source) at an OLR of $0.35 \mathrm{Kg} \mathrm{COD/cum-day.} \mathrm{On} \mathrm{the} \mathrm{whole} \mathrm{the} \mathrm{reactor}$ was operated for a total number of 53 cycles (53 days) including startup period. After 17 days of startup operation a consistent performance with respect to COD removal was observed. Substrate degradation rate (SDR) profile also revealed a consistent substrate uptake rate $(0.329 \mathrm{Kg} \mathrm{COD/cum-day)}$ after 17 days of inoculation.

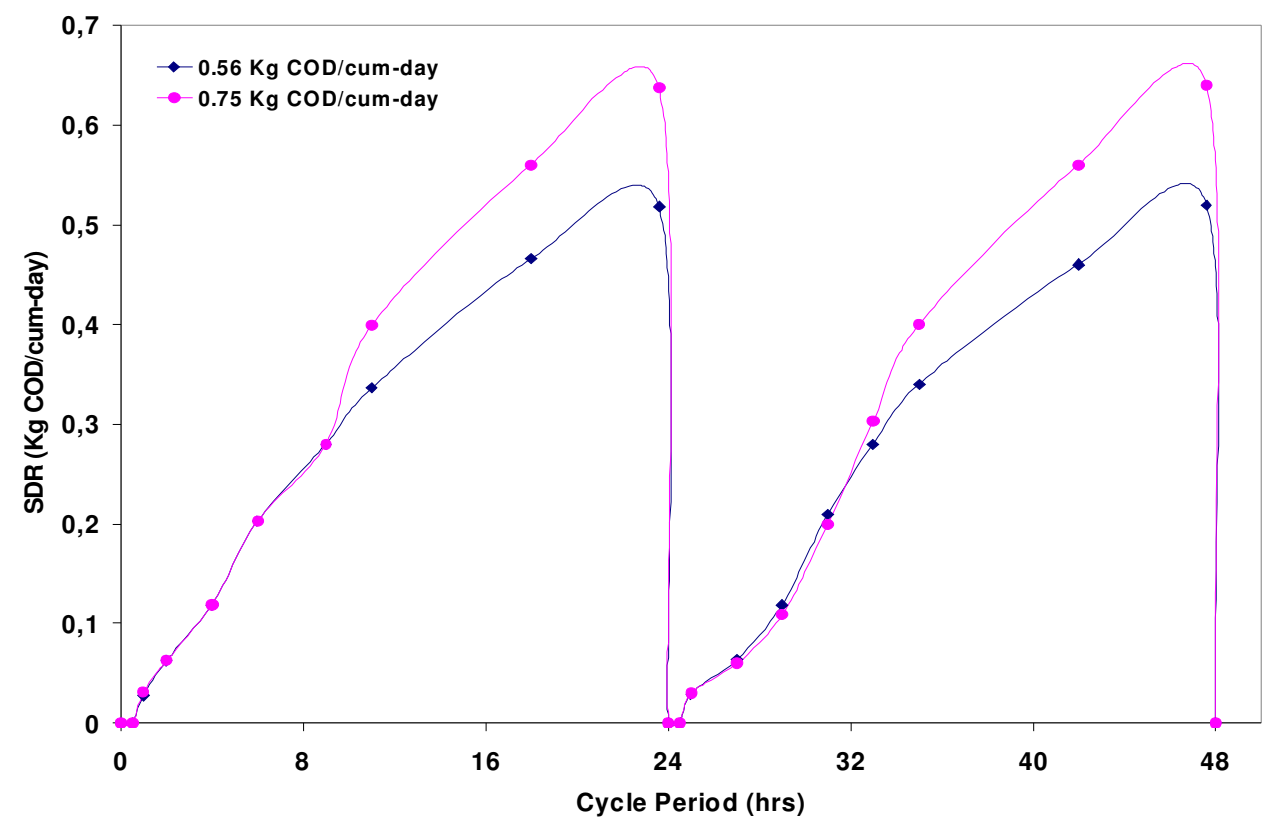

Figure 2. SDR variation during two consecutive cycle operation

On 23rd day of startup the reactor was fed with synthetic azo dye wastewater (OLR$0.56 \mathrm{Kg} \mathrm{COD} /$ cum-d). COD removal efficiency of $91 \%$ was observed after $37^{\text {th }}$ day of operation (15 days after dye wastewater feeding) (Fig. 1). After achieving stable performance, the reactor was further operated with higher OLR (0.75 Kg COD/cum-d), where the reactor yielded $89 \%$ of COD removal efficiency after 39 days of startup (6 days after OLR shift). With continued operation, the reactor showed enhanced performance with respect to COD removal efficiency and attained stable conditions rapidly. The SDR profiles are consistent and comparable with the COD removal profiles for all the studied cases. SDR of $0.52 \mathrm{Kg} \mathrm{COD/cum-d} \mathrm{was} \mathrm{observed} \mathrm{at} 0.56 \mathrm{Kg}$ $\mathrm{COD} /$ cum-d of OLR at stable operating conditions, while with $0.75 \mathrm{Kg} \mathrm{COD} / \mathrm{cum}-\mathrm{d}$ of OLR, the reactor showed maximum SDR of $0.64 \mathrm{Kg} \mathrm{COD/cum-d.} \mathrm{The} \mathrm{dye} \mathrm{color} \mathrm{(OD-}$ $617 \mathrm{~nm}$ ) was also monitored during the reactor operation. 


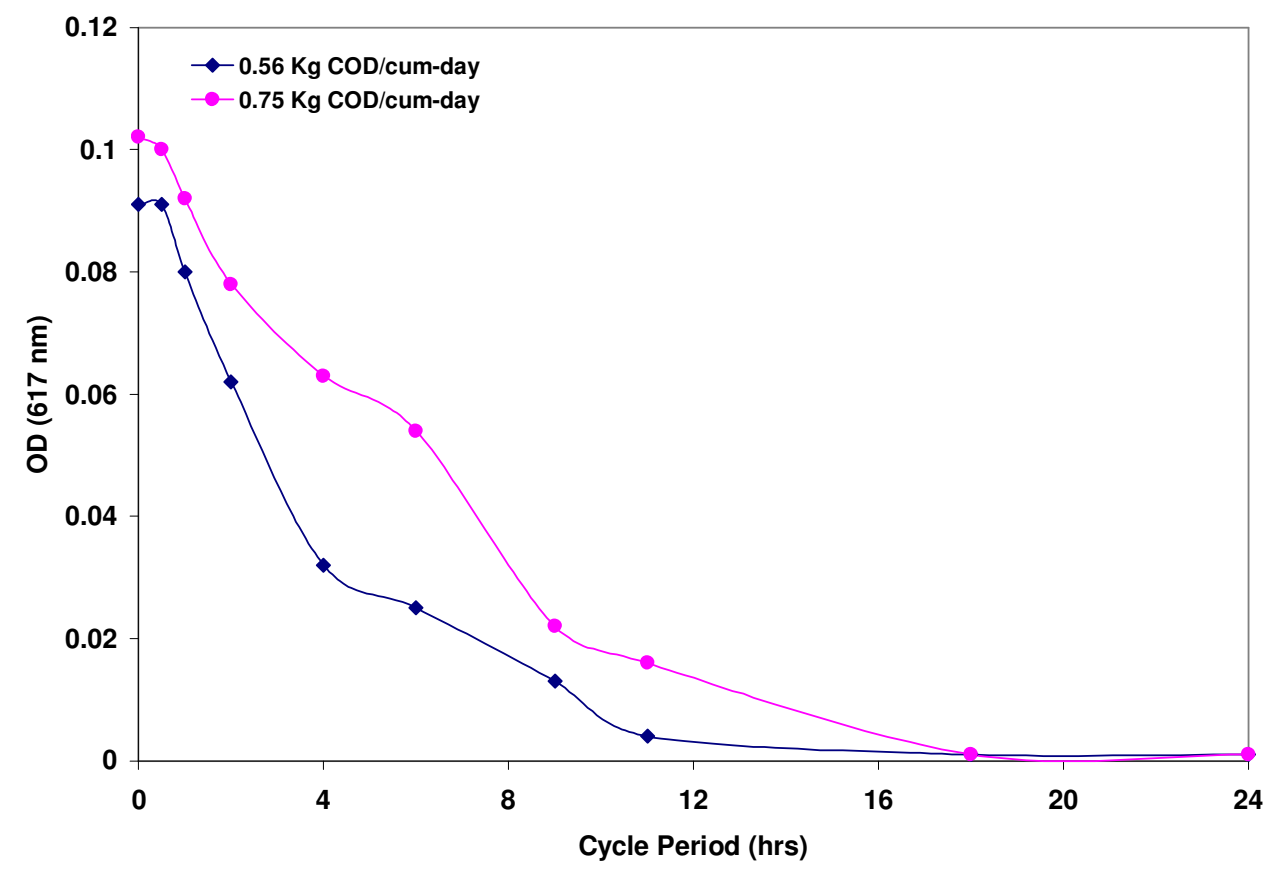

Figure 3. Color removal variation during SBR cycle operation

The colour removal was found to be initially rapid and approached a maximum after 10 hours $(0.56 \mathrm{Kg} \mathrm{COD} /$ cum-d) and 18 hours (6 days for $0.75 \mathrm{Kg} \mathrm{COD} / \mathrm{cum}-\mathrm{d}$ ) of cycle period. The COD removal rate was uniform throughout the reactor operation for the both OLRs studied and attained equilibrium after $20 \mathrm{~h}$ of the cycle operation. For achieving stable performance, the reactor showed to require 15 days at operating OLR of $0.56 \mathrm{Kg} \mathrm{COD} / \mathrm{cum}-\mathrm{d}$ and 6 days at operating OLR of $0.75 \mathrm{Kg} \mathrm{COD} /$ cum-d. Consolidated data of SBR performance at OLRs studied are presented in Table 2.

Table 2. Performance of SBR at various OLRs studied

\begin{tabular}{|c|c|c|c|c|}
\hline $\begin{array}{c}\text { OLR } \\
\text { (Kg COD/cum- } \\
\text { day) }\end{array}$ & $\begin{array}{c}\text { COD removal } \\
\text { efficiency (\%) }\end{array}$ & $\begin{array}{c}\text { Colour } \\
\text { removal } \\
\text { Efficiency } \\
(\%)\end{array}$ & $\begin{array}{c}\text { Time to achieve } \\
\text { stable } \\
\text { performance } \\
\text { (days) }\end{array}$ & $\begin{array}{c}\text { F/M ratio } \\
\text { (as COD) } \\
\text { range }\end{array}$ \\
\hline $\begin{array}{c}0.35 \\
\text { (startup phase) }\end{array}$ & $92 \pm 1.4$ & - & 22 & $0.129-0.096$ \\
0.56 & $92 \pm 1.9$ & 100 & 15 & $0.179-0.150$ \\
0.75 & $92 \pm 1.2$ & 100 & 6 & $0.197-0.187$ \\
\hline
\end{tabular}

The influent $\mathrm{pH}$ of 6.9 was introduced during the feeding and with the exhaustion of cycle period, the aqueous phase $\mathrm{pH}$ showed a gradual increase and approached 8.0 at the end of the reaction phase. 


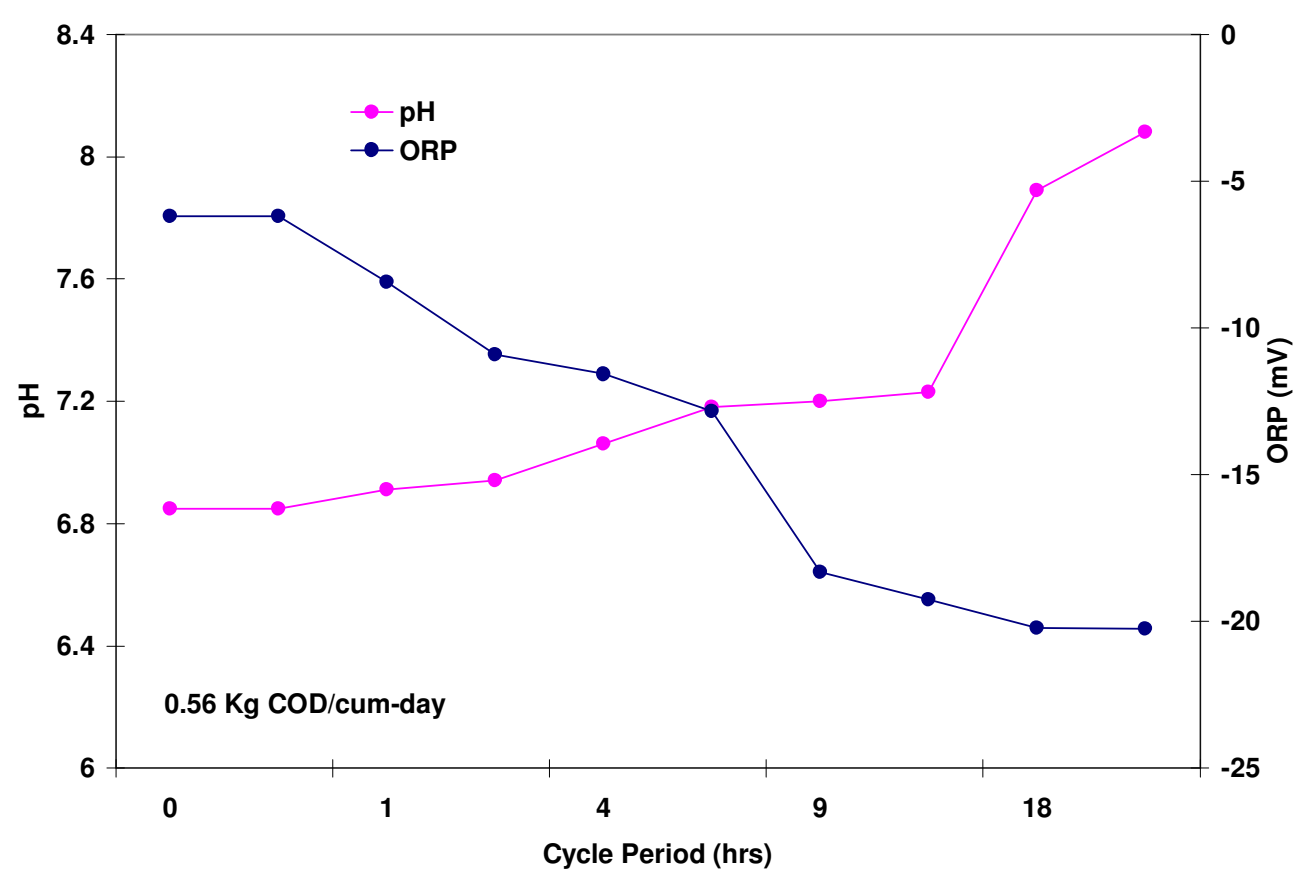

Figure 4. Variation of $p H$ and ORP during SBR cycle operation.

ORP (mV) profile visualized a mirror image to $\mathrm{pH}$. Oxygen consumption/transfer capacity often is one of the important factors that limit the capacity of suspended growth biological systems. Oxygen consumption rate (OCR) showed a rapid increase $\left(0.098 \mathrm{mg} \mathrm{O}_{2} / \mathrm{min}\right)$ during the initial phase of the cycle operation (upto 4 hours) for both the OLRs studied.

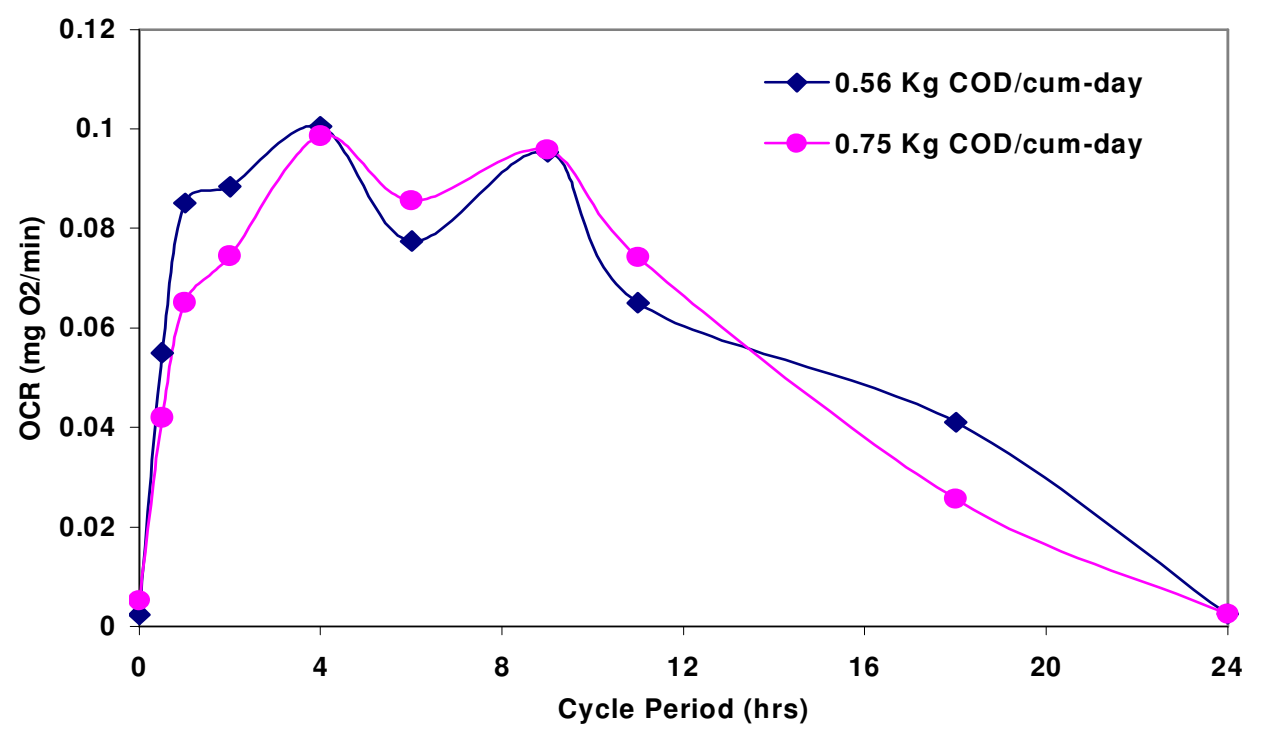

Figure 5. OCR profile during SBR cycle operation. 
Subsequently, the OCR showed a gradual reduction in the values. OCR is expected to increase with sludge retention time due to higher endogenous respiration requirements. Sludge volume index (SVI) was monitored during the end of each cycle operation before the decant phase. Initially at the startup phase, SV was $150 \mathrm{ml}(0.56 \mathrm{~kg}$ COD/cum-d) and with increase in OLR also SV values showed similar values (45.9 ml). This may be attributed to the fact that increases in OLR relatively negligible inhibition in the process operation and its metabolic activities. The SVI was found to be good throughout the reactor operation (180 at $0.56 \mathrm{~kg}$ COD/cum-d and 198 at $0.75 \mathrm{~kg}$ $\mathrm{COD} /$ cum-d), which is less than 100. SVI of 100 is commonly used as the limit between good and poor settling sludge. It is reported that the sludge settles well and at high concentration of DO in periodically operated suspended growth systems produces sludge with good settling and thickening properties (floc high compactness) [21,25]. In this study aqueous phase DO was maintained consistently in the range of 2.5 to $3.0 \mathrm{mg} / \mathrm{l}$ and sludge showed good settling properties. F/M ratio was in the range of 0.129 to 0.096 during the startup phase of the reactor (Table 2). The F/M ratio showed more or less similar values for the two OLRs studied (0.179-0.150 at $0.75 \mathrm{~kg} \mathrm{COD} / \mathrm{cum}-\mathrm{d}$ and $0.197-0.187$ at $0.56 \mathrm{~kg} \mathrm{COD} / \mathrm{cum}-\mathrm{d})$, which indicates non-inhibition of process due to high dye substrate loading conditions. SS concentration varied in the narrow range of $4200 \mathrm{mg} / \mathrm{l}$ to $4500 \mathrm{mg} / \mathrm{l}$ and VSS concentration varied in between $2500 \mathrm{mg} / \mathrm{l}$ to 3200 $\mathrm{mg} / \mathrm{l}$ during the reactor operation.

VSS/SS ratio was 0.65 initially during start up phase and with increase in cycle period the ratio showed a consistent increase and the viability of biomass increased with the increase in operating OLR (VSS/SS ratio of 0.74 [0.75 Kg COD/cum-d]).

Normally in the traditional aerobic wastewater treatment systems relatively less COD reduction is observed for dye based wastewater $[1,2,26]$ while anaerobic processes demonstrated efficiency in reducing the colour of the wastewater [27-29]. Studies showed that anaerobic processes can be used to decolorize dye wastewater which improve the wastewater biodegradability for subsequent aerobic treatment [1, 3, 30-32]. Under anaerobic conditions, fermentative bacteria can reduce the dyes by cleaving the azo bond. It is a prerequisite to have anaerobic conditions to initially breakdown the dye molecule prior to the aerobic mineralization for effective treatment. To overcome the problem of the relative recalcitrance of azo dye breakdown products under anaerobic conditions, a two-stage treatment process was reported [33, 34]. In the first anaerobic stage, the azo dye was readily reduced to the corresponding colourless aromatic amines, which are then metabolized easily under aerobic conditions [2]. However in conventional biological process, the aerobic process is seldom capable of degrading the dye molecule while anaerobic process alone cannot handle the complete mineralization of the dye molecule. On the contrary, the SBR operation facilitates the inclusion of anoxic phase in addition to the aerobic phase in a single reactor during the sequence phase operation. In this study during feed phase $(30 \mathrm{~min})$ and subsequent settle and decant phase $(30 \mathrm{~min})$ in the cycle operation anoxic conditions persist in the reactor microenvironment. The anoxic (settle, decant and fill) microenvironment facilitates the initial breakdown of dye molecule and subsequently the products formed will be further mineralized in the aerobic phase (react). Size of the biofilm floc also has significant influence on the extent and presence of the anoxic zone [21]. Normally biofilm particle size in ASP is in the range of $10-110 \mu \mathrm{m}$. In the present study the suspended biofilm size in the reactor was in the range of 90-600 $\mu \mathrm{m}$ (average size $340 \mu \mathrm{m}$ ) and it is reported that the biofilm floc of $200 \mu \mathrm{m}$ size and above will have anoxic microniches in 
the internal part of the flocs [35]. Venkata Mohan et al [21] reported sulphate reduction in SBR reactor configured with suspended growth due to induced anoxic environment. Effective dye materialization in the periodic discontinuous process may be attributed to the induced anoxic zone during cycle operation along with the anoxic environment prevailing in the suspended biomass. Time varying individual components of incoming wastewater in each process steps in periodic discontinuous operation facilitates microorganisms to be placed under nutritional changes from feast to famine state and it is also reported that periodic operations with altering feast and famine conditions results in high uptake of substrate and also better setability of the biomass [36]. Grau et al [37] in their accumulation regeneration theory stated that the more the microorganisms are able to store substrate during imposed transient phase, subsequent reuse for growth during substrate limited conditions have competitive advantage. Recent research indicated that the sequential feast and famine conditions enhance the overall performance of the biological system [38] especially for complex chemical wastewater treatment $[21,23]$.

\section{Conclusions}

It can be concluded from this experiments that the dye containing wastewater can be efficiently treated using periodic discontinuous operation. The induced anoxic conditions prevailing in the reactor due to the sequential batch operation facilitated initial azo reduction, which on subsequent aerobic process resulted in dye minerilization. The reactor performance was not inhibited at the studied two organic loading rates. The rapid startup and stabilization showed one of the important advantages of the SBR. Enforced short-term unsteady state conditions coupled with periodic exposure of the microorganisms to defined process conditions in SBR operation resulted in efficient performance for the treatment of dye based wastewater. Unlike the continuos biological operations the SBR process facilitates each individual operation to be carried out in the single reactor, which is considered to be flexible and moreover economical.

Acknowledgement. One of the authors (SVM) gratefully acknowledges Alexander von Humboldt (AvH) Foundation for giving the fellowship for carrying research on sequencing batch reactor technology and NCR is thankful to CSIR, Government of India for providing him Senior Research Fellowship.

\section{REFERENCES}

[1] Stolz, A. (2001): Basic and applied aspects in the microbial degradation of azo dyes. Appl. Microbial. Biotechnol. 56: 69-80.

[2] McMullan, G., Meehan, C.A. Conneely, N. Kirby, T. Robinson, P. Nigam, I., Banat M., Marchant, R. (2001): Microbial decolourisation and degradation of textile dyes. - Appl. Microbial. Biotechnol. 56: 81-87.

[3] Correia, V.M., Stephenson, T., Judd, S.J. (1994): Characterization of textile wastewater: a review. - Environ. Technol. 15: 917-919.

[4] O’Neill, F., Hawkes, R., Hawkes, D.L., Lourenço, N.D., Pinheiro, H.M., Wouter, D. (1999): Colour in textile effluents-sources, measurement, discharge consents and simulation: a review. J. Chem. - Technol. Biotechnol. 74: 1009-1018. 
[5] Venkata Mohan, S. (1997): Removal of textile dye colour from aqueous solution by adsorption onto coal/coal based sorbents - PhD Thesis, Sri Venkateswara University, Tirupati, India.

[6] Venkata Mohan, S., Krishna Prasad, K., Chandrasekhara Rao, N. and Sarma, P.N. (2005): Enzyme mediated degradation of acid azo dye in aqueous phase. - Chemosphere 58: 1097-1105.

[7] Venkata Mohan, S., Vijaya Bhaskar, Y. and Karthikeyan, J. (2004): Biological decolorization of azo dyes by algal spirogyra species. - Int. J. Environ. Poll. 21 (3): 210222.

[8] Kulla, H. G. (1981): Aerobic bacterial decolorization of azo dye. FEMS. - Microbiol. Letts. 12: 387-399.

[9] Wilderer, P.A., Irvine, R.L. and Goronszy, M.C. (2001): Sequencing batch reactor technology. - Scientific and Technical Report, IWA Publishing 10.

[10] Lefebvre, O., Vasudevan, N., Torrijos, M., Thanasekaran, K. and Moletta, R. (2005): Halophilic biological treatment of tannery soak liquor in a sequencing batch reactor. Wat Res. 39(8): 1471-1480.

[11] Daims, H. (2001): Nitrification in sequencing biofilm batch reactor. - Wat. Sci. Technol. 43 (3): 9-18.

[12] Yu, L. and Tay, T. (2005): Denitrification on poly- $\beta$-hydroxybutyrate in microbial granular sludge sequencing batch reactor. - Wat. Res. 39(8): 1503-1510.

[13] Dassanyakee, C. and Irvine, R.L. (2001): An enhanced biological phosphorus removal (EBPR) control strategies for SBR's. - Wat. Sci .Technol. 43(3): 183-190.

[14] Ong, S., Toorisaka, E., Hirata, M. and Hano, T. (2005): Treatment of azo dye Orange II in aerobic and anaerobic-SBR systems. - Proc. Biochem. 40: 2907-914.

[15] Zhuang, W., Tay, J., Yi, S. and Tay, S.T. (2005): Microbial adaptation to biodegradation of tert-butyl alcohol in a sequencing batch reactor. - J. Biotechnol. 118: 45-53.

[16] Yalmaz, G. and Oztusk, I. (2001): Biological ammonia removal from an aerobically pretreated lechates in sequencing batch reactors. - Wat. Sci. Technol. 43 (3): 307-314.

[17] Giraja, S. and Wilderer, P.A. (2001): Characterization and treatment of the liquid effluents from an aerobic digestion of biogenic solid waste. - Wat. Sci. Technol. 43(3): 265-274.

[18] Buitrón, G., Soto, G., Vite, G. and Moreno, J. (2001): Strategies to enhance the biodegradation of toxic compounds using discontinuous process. - Wat. Sci. Technol. 43 (3): 283-290.

[19] Venkata Mohan, S., Nancharaiah, Y.V., Flankentof, F.C., Wattiau, P., Wuertz, S. and Wilderer, P.A. (2002): Monitoring the conjugal transfer of plasmid PWWO from Pseudomonas putida in Sequencing Batch Biofilm Reactor, - Proc of VAAM Conference, Gottingen.

[20] Venkata Mohan, S., Sirisha, R., Sarma, P.N. and Reddy, S.J. (2004): Degradation of chlorpyrifos contaminated soil by bioslurry reactor operated in sequencing batch mode: Bioprocess monitoring. - J. Haz. Mat. B11 6: 39-48.

[21] Venkata Mohan, S., Chandrasekhar Rao, N., Krishna Prasad, K., Madhavi, B.T.V. and Sarma, P.N. (2005): Treatment of complex chemical effluents by sequencing batch reactor (SBR) with aerobic suspended growth configuration. - Proc. Biochem. 40 (5): 1501-1508.

[22] Venkata Mohan, S., Chandrasekhara Rao, N., Krishna Prasad, K., Muralikrishna, P., Sreenivasa Rao, R. and Sarma, P.N. (2005): Anaerobic treatment of complex chemical wastewater in a sequencing batch biofilm reactor: process optimization and evaluation of factors interaction using the Taguchi dynamic DOE methodology. - Biotech. Bioengng. 90 (6): 732-745.

[23] Venkata Mohan, S., Chandrasekhara Rao, N., Krishna Prasad K., and Sarma, P.N. (2005): Bioaugmentation of anaerobic sequencing batch biofilm reactor (ASBBR) with 
immobilized sulphate reducing bacteria (SRB) for treating sulfate bearing chemical wastewater. - Proc. Biochem. 40 (8): 2849-2857.

[24] Standard methods for the examination of water and wastewater (1998): APHA, (20 Ed.) AWWA, WEF: Washington.

[25] Wilen, B. and Balmer, P. (1999): The effect of dissolved oxygen concentration on the structure, size and size distribution of activated sludge flocs. - Wat. Res. 33(2): 391-400.

[26] Carliell, C.M., Barclay, S.J., Naidoo, N., Buckley, C.A., Mullholl, D.A. and Senior, E. (1995): An Investigation Microbial decolourisation of a reactive azo dye under anaerobic conditions. - Water SA. 21(1): 61-69.

[27] Gingell, R. and Walker, R.R. (1971): Mechanisms of azo reduction by Streptococcus Faecalis II - The role of soluble Favines. - Xenobiotica 1: 231-239.

[28] Bhattacharya, K., Raha, S. and Majumdar, M.R. (1989): Fate and effect of azo dye on an anaerobic-aerobic system. - In 44th Purdue Industrial Waste Conference Proceedings. Purdue University West Lafayette, pp. 295-297.

[29] Banat, I.M., Nigam, P., Singh, D. and Roger, M. (1996): Microbial decolorization of textile dye containing effluents-a review. - Biores. Tech. 58: 217-227.

[30] Ong, S., Toorisaka, E., Hirata, M. and Hano, T. (2005): Decolorization of azo dye (Orange II) in a sequential UASB-SBR system. - Sep. Purif. Technol. 42(3): 297-302.

[31] Brown, D. and Hamburger, B. (1987): The degradation of dyestuffs: Part IIIInvestigations of their ultimate degradability. - Chemosphere 16(7): 1539-1553.

[32] Chinwetkitvanich, S., Tuntoolvest, M. and Panswad, T. (2000): Decolorization of reactive dyebath Effluents by a two-stage UASB system with Tapioca as a co-substrate. Wat. Res. 34 (8): 2223-2232.

[33] O'Neill, C., Lopez, A., Esteves, S., Hawkes, F. R., Hawkes, D.L. and Wilcox, S. (2000): Azo-dye degradation in an anaerobic-aerobic treatment system operating on simulated textile effluent. - Appl. Microbiol. Biotechnol. 53: 249-254.

[34] Panswad, T. and Luangdilok, W. (2000): Decolorization of reactive dyes with different molecular structures under different environmental conditions. - Wat. Res. 34(17): 41774184.

[35] Pochana, K., Keller, J. and Paul, L. (1999): Model development for simultaneous nitrification and denitrification. - Wat. Sci. Tech. 39(1): 235-243.

[36] Chiesa, S.C., Irivine, R.L. and Manning Jr, J.F. (1985): Feast/famine growth environment and activated sludge population selection. - Biotechnol. Bioengng. 27: 562-569.

[37] Grau, P., Chudaba, J. and Dohnyos, J. (1982): Theory and practice of accumulation regeneration approach to control of activated sludge filamentous bulking (Edt: B. Chamber and J. Tomlinson ) - Ellis Horward Press, Chichester.

[38] Watanabe, K., Miyashita, M. and Harayama, S. (2000): Starvation improves survival of bacteria introduced into activated sludge. - App. Environ. Microbiol. 66: 3905-3910. 